\title{
Studi Kasus Peningkatan Pengetahuan dan Sikap Terhadap Pencegahan Pelecehan Seksual Melalui Media Video dan Leaflet Pada Siswa Sekolah Dasar di Manggarai Timur
}

\author{
"Maria Efshinta Faustina1), Nur Asniati Djaali²), Eko Setyo Pambudi ${ }^{3)}$ \\ Program Studi Magister Kesehatan Masyarakat, Fakultas Kesehatan Masyarakat, \\ Universitas Mohamamd Husni Thamrin
}

Corresponden author: efshintafaustina@gmail.com

Received : 30 Februari $2021 \quad$ Accepted : 25 Maret $2021 \quad$ Published: 30 Maret 2021

\begin{abstract}
ABSTRAK
Pelecehan seksual suatu perilaku yang menjurus pada hal-hal yang berkaitan dengan hubungan seks, berupa kata-kata maupun perbuatan yang tidak disetujui korbannya. Pihak yang sering mendapatkankan pelecehan seksual adalah anak anak. Hal ini karena anak-anak mudah dipengaruhi dan kurangnya pengetahuan tentang plecehan seksual. Laporan Dinas sosial NTT tahun 2019 jumlah kasus pelecehan seksual yang terlapor berjumlah 406. Tujuan penelitian ini adalah mengetahui studi kasus promosi kesehatan peningkatan pengetahuan dan sikap terhadap pencegahan pelecehan seksual melalui media video dan leaflet pada siswa sekolah dasar. Metode penelitian yang digunakan quasi experiment posttest pretest with control group design. Tempat penelitian di 3 sekolah dasar di NTT Kab. Manggarai Timur yang dibagi menjadi 3 kelompok yaitu; sekolah 1 promosi kesehatan menggunakan media video, sekolah 2 promosi kesehatan menggunakan media leaflet dan sekolah 3 promosi kesehatan tanpa media. Populasi penelitian peserta didik kelas VI di SDN Rejo, SDI Beamuring, dan SDK Arus. Penentuan hasil menggunakan uji Wilcoxon. Promosi kesehatan menggunakan media video dan leaflet efektif meningkatkan pengetahuan pada ke 3 kelompok sekolah, dengan p-value.000. Promosi kesehatan tanpa media pada kelompok 3 dengan P-value 0,18 dan P-value pada kelompok 1 sebesar 0,1, memberi arti penggunaan video tidak efektif mengubah sikap responden. Promosi kesehatan menggunakan media leaflet pada kelompok 2 efektif mengubah sikap responden.
\end{abstract}

Kata Kunci : Plecehan Seksual; Media Promosi Kesehatan; Pencegahan Plecehan Sexsual pada Anak.

\section{ABSTRACT}

Sexual harassment is a behavior that leads to matters related to sexual relations, either in the form of words or actions that the victim disapproves of. The most frequently sexually abused are children. In almost every case, children are always victims. This is because children are easily influenced and also because they lack knowledge about sexuality. According to the NTT Social Service Report, cases of sexual abuse that were reported to children that occurred in NTT totaled 406 sexual abuse cases in 2019.

The purpose of this study was to determine health promotion efforts to increase knowledge and attitudes towards prevention of sexual harassment through video media and leaflets for elementary school students.

The research method used was a quasi experiment with post-test and pre-test with control group design. The research site was conducted in three elementary schools in NTT, East Manggarai Regency, which were divided into 3 groups, namely; school 1 was given health promotion using video media, school 2 was given health promotion using leaflet media and school 3 was given health promotion without media.

The population in this study were class VI students at SDN Rejo, SDI Beamuring, and SDK Arus. Determination of results using the Wilcoxon test. Health promotion using video media and leaflet media effectively increased knowledge in all three school groups, with a p-value of.000. Health promotion without media in group 3 with a P-value of 0.18 and P-value in group 1 of 0.1, which means that the use of video is not effective in changing the respondent's attitude. Health promotion using leaflet media in group 2 was effective in changing respondents' attitudes.

Keywords: Sexual Harassment; Health Promotion Media; Prevention of Sexual Abuse in Children. 


\section{PENDAHULUAN}

Pelecehan seksual adalah suatu perilaku yang menjurus pada hal-hal yang berkaitan dengan hubungan seks, baik berupa kata-kata maupun perbuatan yang tidak disetujui oleh korbannya, merendahkan korbannya, atau memanfaatkan korbannya. Pelecehan seksual dapat berupa katakata atau candaan (humor) porno, memperlihatkan bagian tubuh maupun gambar porno, menyentuh bagian tubuh, sampai dengan memaksa melakukan hubungan seksual.

Kelompok yang paling rentan mendapatkan kejahatan asusila adalah anak, sehingga hampir disetiap kasus pelecehan seksual sebagian besar yang menjadi korban adalah anak-anak. Menurut WHO, pelecehan seksual anak adalah keterlibatan seorang anak dalam aktivitas seksual yang tidak sepenuhnya dipahami, tidak ada penjelasan kepadanya yang melanggar norma dan aturan masyarakat. Pelecehan seksual pada anak dan remaja menampati posisi terbanyak, yaitu 50\%-62\% dari bentuk pelecehan lainnya pada anak (UNESCO, 2016), data yang dikumpulkan oleh pusat data dan informasi Komisi Nasional Perlindungan Anak Indonesia (KNPAI) dari tahun 2010 hingga 2014 tercatat sebanyak 2.186.979 kasus pelanggaran hak anak. Sebesar 42-58\% dari pelanggaran kejahatan tersebut dengan korban anak-anak dan pada tahun 2019 KPAI menamukan kasus pelecehan seksual terhadap anak dengan jumlah korban 123 anak yang terjadi di Institusi pendidikan (71 anak perempuan dan 52 anak laki laki). Pelaku pelecehan seksual mayoritas adalah guru (90\%). Kasus pelecehan seksual banyak terjadi pada jenjang SD dikarenakan anak usia SD merupakan golongan rentan, mudah untuk dipengaruhi, diprovokasi, dan belum memiliki pengetahuan terkait pendidikan seksual. Menurut PMKS Provinsi NTT pada tahun 2019, jumlah kasus pelecehan seksual pada anak yang terlapor yang terjadi di NTT adalah sebanyak 406 kasus. Ditemukan sebanyak 146 kasus tejadi di wilayah Kabupaten Manggarai Timur.

Kasus pelecehan seksual di Manggarai Timur seperti fenomena gunung es, hingga saat ini masih banyak kasus pelecehan seksual yang belum dilaporkan. Hal ini disebabkan pelecehan seksual masih menjadi hal yang sangat tabu untuk dilaporkan atau dipublikasikan. Selain itu, adanya pengaruh adat istiadat setempat yang penyelesaian kasus pelecehan seksual, cara untuk meningkatkan pengetahuan kesehatan reproduksi adalah dengan promosi kesehatan. Beberapa studi menamukan bahwa pemberian promosi kesehatan dapat meningkatkan pengetahuan seseorang dan dapat mempengaruhi sikap (Benita, et al., 2012; Lestary, 2014; Udu \& Wiradirani, 2015). Saat ini, banyak media informasi yang dapat diakses untuk memberikan 
pendidikan kesehatan reproduksi dalam upaya pencegahan pelecehan seksual pada anak, antara lain menggunakan media video dan media Leaflet.

Dalam penelitian ini, peneliti akan mengadopsi media video dan media leaflet yang sudah tervalidasi dan digunakan untuk memberikan edukasi dan promosi kesehatan kepada siswa sekolah dasar tentang pendidikan reproduksi dini dan upaya pencegahan pelecehan seksual pada anak. Penelitian ini bertujuan untuk melihat peningkatan pengetahuan dan sikap siswa tentang reproduksi dan pencegahan pelecehan seksual melalui media leaflet dan video.

\section{METODE}

Desain Penelitian ini Quasi Experiment dengan posttest pretest with control group design bertujuan untuk menilai perbedaan perubahan pengetahuan dan sikap melalui promosi kesehatan menggunakan media video, leaflet dan promosi kesehatan tanpa media pada siswa sekolah dasar di Kab Manggarai Timur Provinsi NTT Penentuan sampel yang menggunakan metode sampel jenuh, melalui kuesioner pre-test dan post-test melibatkan 3 sekolah sebagai tempat penelitian yang dijabarkan sebagai berikut: Kelompok 1 Sekolah dasar yang diberikan media video, kelompok 2 media leaflet dan kelompok 3 Promosi kesehatan tanpa menggunakan media, jumlah populasinya kurang dari 30 responden sehingga menggunakan metode non parametrik dengan uji Wilcoxon.

\section{HASIL DAN PEMBAHASAN}

\section{Hasil}

\section{Analisis Univariat}

Sampel dalam penelitian ini adalah anak sekolah dasar dengan rentang usia antara 7 hingga 12 tahun. Berdasarkan hasil penelitian dari 3 kelompok sampel yang berjumlah 51 responden, menunjukan bahwa pada kelompok 1 promosi kesehatan menggunakan media video memiliki kesamaan jumlah sampel dengan kelompok 2 promosi kesehatan menggunakan media leaflet berjumlah 18. Pada kelompok 3 ,promosi kesehatan tanpa media mendapatkan jumlah 15 responden. Responden terbanyak berada dikisaran umur $\leq 11$, berjenis kelamin perempuan, dengan pendidikan orang tua yang tinggi. Budaya yang dianut responden dalam penelitian ini tidak mendukung terkait adanya informasi kesehatan reproduksi upaya pencegahan pelecehan seksual pada anak anak. 
Tabel 1.

Gambaran Skor Tingkat Pengetahuan Kelompok 1

\begin{tabular}{|c|c|c|c|c|c|}
\hline Variabel & Mean & $\begin{array}{c}\text { Median } \\
\text { Modus }\end{array}$ & $\begin{array}{c}\text { Standar } \\
\text { Deviasi }\end{array}$ & $\begin{array}{l}\text { Minimal } \\
\text { Maximal }\end{array}$ & $\mathbf{n}$ \\
\hline \multicolumn{6}{|c|}{ Pengetahuan Kelompok 1} \\
\hline Sebelum & 6.77 & $\begin{array}{l}7 \\
8\end{array}$ & 1.51 & $\begin{array}{l}4 \\
9\end{array}$ & 18 \\
\hline Sesudah & 10.72 & $\begin{array}{l}11 \\
11\end{array}$ & .669 & $\begin{array}{c}9 \\
11\end{array}$ & 18 \\
\hline \multicolumn{6}{|c|}{ Sikap Kelompok 1} \\
\hline Sebelum & 43.22 & $\begin{array}{l}43 \\
42\end{array}$ & 4.40 & $\begin{array}{l}35 \\
49\end{array}$ & 18 \\
\hline Sesudah & 39.77 & $\begin{array}{l}38 \\
38 \\
\end{array}$ & 4.13 & $\begin{array}{l}35 \\
50\end{array}$ & 18 \\
\hline \multicolumn{6}{|c|}{ Pengetahuan Kelompok 2} \\
\hline Sebelum & 5.77 & $\begin{array}{l}6 \\
6\end{array}$ & 1.21 & $\begin{array}{l}3 \\
8\end{array}$ & 18 \\
\hline Sesudah & 9.55 & $\begin{array}{l}10 \\
10 \\
\end{array}$ & .855 & $\begin{array}{c}7 \\
11\end{array}$ & 18 \\
\hline \multicolumn{6}{|c|}{ Sikap Kelompok 2} \\
\hline Sebelum & 32.61 & $\begin{array}{l}32 \\
29\end{array}$ & 6.66 & $\begin{array}{l}14 \\
44\end{array}$ & 18 \\
\hline Sesudah & 43.33 & $\begin{array}{c}43.50 \\
44\end{array}$ & 2.19 & $\begin{array}{l}39 \\
50\end{array}$ & 18 \\
\hline \multicolumn{6}{|c|}{ Pengetahuan Kelompok 3} \\
\hline Sebelum & 7.26 & $\begin{array}{l}7 \\
7\end{array}$ & 2.40 & $\begin{array}{c}3 \\
11\end{array}$ & 15 \\
\hline Sesudah & 10.73 & $\begin{array}{l}11 \\
11 \\
\end{array}$ & 0.79 & $\begin{array}{c}8 \\
11 \\
\end{array}$ & 15 \\
\hline \multicolumn{6}{|c|}{ Sikap Kelompok 3} \\
\hline Sebelum & 35.4 & $\begin{array}{l}37.0 \\
37.0\end{array}$ & 8.01 & $\begin{array}{l}10.0 \\
43.0\end{array}$ & 15 \\
\hline Sesudah & 38.93 & $\begin{array}{l}38.0 \\
38.0\end{array}$ & 1.94 & $\begin{array}{l}38.0 \\
44.0 \\
\end{array}$ & 15 \\
\hline
\end{tabular}

Dari Tabel 1 terlihat berdasarkan uji statistik peningkatan mean pada variabel pengetahuan kelompok 1 ada peningkatan pengetahuan pada responden sebelum dan sesudah diberikan perlakuan, sedangkan pada variabel sikap kelompok 1 terjadi penurunan mean setelah diberikan perlakuan terjadi penurunan mean. Pada variabel pengetahuan kelompok 2 ada peningkatan pengetahuan pada responden sebelum dan sesudah diberikan perlakuan, sedangkan variabel sikap kelompok 2 ada perubahan sikap pada responden sebelum dan sesudah diberikan perlakuan. Pada variabel pengetahuan kelompok 3 ada peningkatan pengetahuan pada responden sebelum dan sesudah diberikan perlakuan, sedangkan variabel sikap pada kelompok 3 ada peningkatan pengetahuan pada responden sebelum dan sesudah diberikan perlakuan. 


\section{Uji Homogenitas}

\section{Tabel 2.}

Uji Homogenitas Variabel Karateristik Kelompok 1, 2 Dan 3

\begin{tabular}{|c|c|c|c|c|}
\hline Variabel & $\begin{array}{c}\text { Sekolah } 1 \\
\text { n }\end{array}$ & $\begin{array}{c}\text { Sekolah } 2 \\
\text { n }\end{array}$ & $\begin{array}{c}\text { Sekolah } 3 \\
\text { n }\end{array}$ & P-Value \\
\hline \multicolumn{5}{|l|}{ Jenis Kelamin } \\
\hline Laki-Laki & 8 & 8 & 6 & \multirow{3}{*}{0,647} \\
\hline Perempuan & 10 & 10 & 9 & \\
\hline Total & 18 & 18 & 15 & \\
\hline \multicolumn{5}{|l|}{ Pendidikan Orang Tua } \\
\hline Rendah & 5 & 9 & 11 & \multirow{3}{*}{0,003} \\
\hline Tinggi & 13 & 9 & 4 & \\
\hline Total & 18 & 18 & 15 & \\
\hline \multicolumn{5}{|l|}{ Budaya } \\
\hline Tidak Mendukung & 13 & 1 & 11 & \multirow{3}{*}{0,063} \\
\hline Mendukung & 5 & 17 & 3 & \\
\hline $\begin{array}{c}\text { Total } \\
\end{array}$ & 18 & 18 & 15 & \\
\hline \multicolumn{5}{|l|}{ Paparan Informasi } \\
\hline Tidak Mendukung & 7 & 13 & 11 & \multirow{3}{*}{0,099} \\
\hline Mendukung & 11 & 5 & 4 & \\
\hline Total & 18 & 18 & 15 & \\
\hline
\end{tabular}

Dari Tabel 2 diatas menjelaskan bahwa sebagian besar data bersifat homogen karena nilai signifikansi $(p)>0,05$. Hal ini menandakan bahwa kelompok data berasal dari populasi dengan varians yang sama dan dapat disimpulkan karateristik responden pada penelitian ini memiliki data yang homogen kecuali jenis kelamin dan variabel budaya. 


\section{Analisis Bivariat}

\section{Uji Wilcoxon}

Tabel 3.

Hubungan Peningkatan Pengetahuan dan Perbedaan Sikap

Promosi Kesehatan Melalui Media Video dan Leaflet

\begin{tabular}{ccccc}
\hline Variabel & Mean & $\begin{array}{c}\text { Standar } \\
\text { Deviasi }\end{array}$ & Beda mean & P-Value \\
\hline Pengetahuan & & & & \\
\hline $\begin{array}{c}\text { Kelompok 1 } \\
\text { Pre-test }\end{array}$ & 6.78 & 1.517 & 3.94 & .000 \\
Post-test & 10.72 & .669 & & \\
\hline Kelompok 2 & & & & \\
$\quad$ Pre-test & 5.78 & 1.215 & 3,78 & .000 \\
Post-test & 9.56 & .856 & & \\
\hline Kelompok 3 & & & & \\
$\quad$ Pre-test & 7.27 & 2.404 & 3.46 & .001 \\
Post-test & 10.73 & .799 & & \\
\hline Sikap & & & & \\
\hline Kelompok 1 & & & & \\
Pre-test & 43.27 & 4.40 & & \\
Post-test & 39.77 & 4.13 & 3.5 & .110 \\
\hline Kelompok 2 & & & & \\
Pre-test & 32.61 & 6.66 & & \\
Post-test & 43.33 & 2.19 & 10,72 & \\
\hline Kelompok 3 & & & & \\
Pre-test & 35.40 & 8.01 & 3,53 & \\
Post-test & 38.93 & 1.94 & & \\
\hline
\end{tabular}

\section{Uji Kruskal Walis}

Tabel 4.

Perbedaan Variabel Pengetahuan dan Sikap Kelompok 1 dan Kelompok 2

\begin{tabular}{lcccc}
\hline \multicolumn{5}{c}{ Ranks } \\
\hline & Sekolah & n & Mean Rank & Asymp. Sig. \\
\hline \multirow{2}{*}{ Pengetahuan } & Kelompok 1 & 18 & 9.97 & \multirow{2}{*}{0.000} \\
& Kelompok 2 & 18 & 27.03 & \\
\hline \multirow{2}{*}{ Sikap } & Kelompok 1 & 18 & 10.42 & \multirow{2}{*}{0,00} \\
& Kelompok 2 & 18 & 26.58 & \\
\hline
\end{tabular}

Tabel 5.

Perbedaan Variabel Pengetahuan dan Sikap Kelompok 1 dan Kelompok 3

\begin{tabular}{ccccc}
\hline \multicolumn{5}{c}{ Ranks } \\
\hline Sekolah & n & Mean Rank & Asymp. Sig. \\
\hline Pengetahuan & Kelompok 1 & 18 & 10.36 & \multirow{2}{*}{0,000} \\
& Kelompok 3 & 15 & 24.97 & \\
\hline Sikap & Kelompok 1 & 18 & 12.89 & \multirow{2}{*}{0,007} \\
& Kelompok 3 & 15 & 21.93 & \\
\hline
\end{tabular}


Tabel 6.

Perbedaan Variabel Pengetahuan dan Sikap Kelompok 2 dan Kelompok 3

\begin{tabular}{ccccc}
\hline \multicolumn{5}{c}{ Ranks } \\
\hline & Sekolah & n & Mean Rank & Asymp. Sig. \\
\hline Pengetahuan & Kelompok 2 & 18 & 17.67 & \multirow{2}{*}{.043} \\
& Kelompok 3 & 15 & 16.20 & \\
\hline Sikap & Kelompok 2 & 18 & 21.31 & \multirow{2}{*}{005} \\
& Kelompok 3 & 15 & 11.83 & \\
\hline
\end{tabular}

\section{Pembahasan}

\section{Hubungan Peningkatan Pengetahuan Dengan Promosi Kesehatan Menggunakan Media}

\section{Video Pada Kelompok 1}

Hasil uji Wilcoxon pada kelompok 1 memperlihatkan adanya perbedaan pengetahuan sebelum dan sesudah diberikan perlakuan dengan nilai $p$-value sebesar 000 (Asymp.sig < 0, 05.) Hal ini terlihat dari rata-rata skor variable pengetahuan sebelum dilakukan promosi kesehatan menggunakan media video sebesar 6.78 dengan standar deviasi sebesar 1.517 menjadi 10.72 (perbedaan mean 3.94) dengan standar deviasi 0,669. Artinya terdapat pengaruh promosi kesehatan dengan menggunakan media video terhadap peningkatan pengetahuan siswa.

Media video yang digunakan dalam promosi kesehatan kelompok 1 sangat efektif meningkatkan pengetahuan responden yang disebabkan media video yang digunakan sudah tervalidasi. Materi video yang disajikan dalam bentuk animasi dikemas secara sederhana dan dipaparkan secara jelas sehingga mudah dipahami dan diminati.

\section{Hubungan Peningkatan Pengetahuan Dengan Promosi Kesehatan Menggunakan Media}

\section{Leaflet Pada Kelompok 2}

Hasil uji Wilcoxon pada kelompok 2 memperlihatkan adanya perbedaan pengetahuan sebelum,sesudah diberikan perlakuan dengan nilai p-value sebesar 000 (Asymp.sig < 0, 05.) terlihat dari rata-rata skor variable pengetahuan sebelum dilakukan promosi kesehatan menggunakan media leaflet sebesar 5.78 dengan standar deviasi sebesar 1.215 menjadi 9, 56 (perbedaan mean 3.78) dengan standar deviasi 0,856. Artinya terdapat pengaruh promosi kesehatan dengan menggunakan media leaflet terhadap peningkatan pengetahuan siswa.

Hasil penelitian yang telah dilakukan di kelompok 2 promosi kesehatan dengan bantuan media cetak (leaflet) sanggatlah efektif meningkatkan pengetahuan siswa karena media leaflet dapat dibaca berulang kali sehingga materi informasi yang diberikan dengan mudah sehingga mampu mempengaruhi daya ingat siswa dalam jangka waktu yang lebih lama. 


\section{Hubungan peningkatan Pengetahuan Dengan Promosi Kesehatan tanpa Menggunakan} Pada Kelompok 3

Hasil uji Wilcoxon pada kelompok 3 memperlihatkan adanya perbedaan pengetahuan sebelum dan sesudah diberikan perlakuan dengan nilai $p$-value sebesar 000 (Asymp.sig < 0, 05) dan mendapatkan nilai rata-rata variabel pengetahuan sebelum diberikan perlakuan sebesar 7.27 dengan standar deviasi sebesar 2.404. Setelah dilakukan promosi kesehatan terjadi peningkatan nilai rata-rata menjadi 10, 73 (perbedaan mean 3.46) dengan standar deviasi 0,799. Artinya terdapat pengaruh promosi kesehatan tanpa media terhadap peningkatan pengetahuan.

Berdasarkan hasil penelitian ini, Siswa sebagai responden dalam penelitian ini mengalami peningkatan pengetahuan sebelum dan sesudah diberikan perlakuan. Hal ini disebabkan karena saat promosi kesehatan ini dilakukan, responden sangat antusias sehingga mampu meningkatkan kosentrasi dan menambah pengetahuan dibandingkan ketika responden belum mendapatkan informasi reproduksi sebagai upaya pencegahan pelecehan seksual dari sekolah dan pelayanan kesehatan.

\section{Hubungan Sikap Dengan Promosi Kesehatan Menggunakan Media video Pada Kelompok 1}

Hasil uji Wilcoxon pada kelompok 1 memperlihatkan perbedaan sikap sebelum dan sesudah diberikan perlakuan dengan nilai $p$-value sebesar 0,11 pada nilai rata rata variabel sikap sebelum dilakukan promosi kesehatan dengan media video sebesar 43, 27 dengan standar deviasi sebesar 4.40. Setelah dilakukan promosi kesehatan variabel sikap mengalami penurunan nilai rata rata menjadi 39, 77 (perbedaan nilai mean sebesar 3.5) dengan standar Deviasi 4.13. Artinya diketahui jika nilai Asymp.sig < 0, 05 maka tidak terdapat pengaruh promosi kesehatan dengan media video terhadap perubahan terhadap sikap siswa.

Berdasarkan hasil penelitian, didapatkan media video tidak efektif dalam mengubah sikap, karena media video yang diberikan hanya satu kali penayangan. Selain itu pola pemikiran siswa masih dipengaruhi oleh budaya dan lingkungan, sehinggga pengetahuan yang dimiliki belum bisa diterapkan kedalam bentuk sikap.

\section{Hubungan Sikap Dengan Promosi Kesehatan Promosi Kesehatan Menggunakan Media Leaflet Pada Kelompok 2}

Hasil uji Wilcoxon pada kelompok 2 memperlihatkan perbedaan sikap sebelum dan sesudah diberikan perlakuan dengan nilai $p$-value sebesar 0,002 . Nilai rata rata variabel sikap pada kelompok 2 sebelum dilakukan promosi kesehatan dengan media Leaflet sebesar 32.61 
dengan standar deviasi sebesar 6.66. Setelah dilakukan promosi kesehatan dengan leaflet, variabel sikap mengalami perubahan yang signifikan menjadi 43, 33 (perbedaan nilai mean sebesar 10.72) dengan standar Deviasi 10.72.

Berdasarkan hasil penelitian ini media leaflet merupakan alat promosi sederhana yang mudah digunakan, berisi cerminan kebiasaan, yang mudah dimengerti oleh responden dalam bentuk gambar, tulisan maupun kombinasi, dapat dibaca berulang kali sehingga materi informasi yang diberikan dengan mudah dapat mempengaruhi daya ingat siswa dalam jangka waktu yang lebih lama dan efektif meningkatkan pengetahuan sampai diproses perubahan sikap.

\section{Hubungan Sikap Dengan Promosi kesehatan Pada Kelompok 3}

Hasil uji Wilcoxon pada kelompok 3 memperlihatkan tidak adanya perbedaan sikap sebelum dan sesudah diberikan perlakuan dengan nilai $p$-value sebesar 0,18 . Nilai rata rata variabel sebelum dilakukan promosi kesehatan sebesar 35.40 dengan standar deviasi sebesar 8.01. Setelah dilakukan promosi kesehatan terjadi peningkatan nilai rata-rata menjadi 38, 93 (perbedaan nilai mean sebesar 3,53) dengan standar deviasi 1.94. Promosi kesehatan tanpa media tidak efektif dalam merubah sikap siswa.

Berdasarkan hasil penelitian ini, didapatkan peneliti promosi kesehatan tanpa media kurang efektif untuk mengubah sikap responden hal ini disebabkan media dalam promosi kesehatan adalah komponen integral dari sistem promosi kesehatan.

\section{SIMPULAN DAN REKOMENDASI}

Dari hasil penelitian yang telah dilakukan telah terjadi peningkatan pengetahuan siswa sebelum dan sesudah diberikan promosi kesehatan menggunakan media video (kelompok 1 dengan perbedaan mean 3.94 dan p-value $=0.000)$ dan leaflet $($ kelompok 2 dengan perbedaan mean 3.78 dan -value $=0.000$ ); terjadi perubahan sikap siswa sebelum dan sesudah diberikan promosi kesehatan menggunakan media leaflet (kelompok 2 dengan beda mean 10,72 dan pvalue $=0.000)$, sedangkan tidak tejadi perubahan sikap pada kelompok 1 yang diberikan promosi kesehatan dengan menggunakan media video (perbedaan nilai mean sebesar 3.5 dengan P-value $=0,110$ ); Peningkatan pengetahuan pada kelompok 1 yang diberikan perlakuan dengan media video (mean rank 9,97) lebih rendah dibandingkan dengan kelompok 2 yang diberi perlakuan media leaflet (27.03). Peningkatan pengetahuan pada kelompok 1 yang diberikan perlakuan media video (mean rank 10.36) lebih rendah dibandingkan dengan yang diberi perlakuan tanpa media pada kelompok 3 ( mean rank 24,97); Perubahan sikap pada 
kelompok 1 yang diberikan perlakuan dengan media video (mean rank 10,42) lebih rendah dibandingkan dengan yang diberi perlakuan dengan kelompok 2 menggunakan media leaflet (mean rank 26,58). Perubahan sikap pada kelompok 1 yang diberikan perlakuan dengan media video (mean rank 12.89) lebih rendah dibandingkan dengan `kelompok 3 yang diberi perlakuan tanpa media (mean rank 21,93); Terdapat peningkatan pengetahuan ( $\mathrm{p}$-value $=0,000$ ) dan perubahan sikap $(\mathrm{p}$-value $=0,000)$ pada kelompok 2 yang diberikan perlakuan dengan menggunakan media leaflet; Terjadi peningkatan pengetahuan $(p$-value $=0,000)$ dan tidak terdapat perbedaan sikap $(\mathrm{p}=$ value $=0,110)$ pada kelompok 1 yang diberikan perlakuan dengan menggunakan media video.

Rekomendasi yang dapat diberikan Bagi institusi sekolah dasar tempat penelitian terlebih khusus kepala sekolah dan guru-guru, diharapkan untuk memberikan pengetahuan kepada orang tua siswa dan anak itu sendiri tentang pentingnya pemberian informasi kesehatan reproduksi dini sebagai upaya pencegahan pelecehan seksual pada anak, diharapkan kepada pihak sekolah untuk mengaktifkan dan bekerja sama dengan fasilitas kesehatan setempat dalam perihal pemberian promosi kesehatan, Menyediakan sarana dan prasarana seperti berupa leaflet yang berhubungan dengan kesehatan reproduksi dan pelecehan seksual terhadap anak,

\section{REFERENSI}

1. Ahmad DN. Membangun Komunikasi dan Pendidikan Berkarakter dalam Keluarga dalam Pengenalan Awal Organ Seksual pada Anak. Bioedukasi J Pendidik Biol. 2017; 8(2):125-33. BPS, https://slemankab.bps.go.id/linkTa belStatis/6ew/id/83 diakses tanggal 20 Oktober 2018

2. Alfabeta Suparno (1999). Metode Penelitian Kuantitatif Kualitatif dan R\&B. Bandung: Kemahiran berkomunikasi Lisan dalam Konteks Instruksional Guru Sekolah Dasar. Jurnal Ilmu Pendidikan, Vol 6, No 1, hal 51-60

3. Akbar NA. (2018). Sepanjang Tahun 2018, Ada 100 lebih Korban Pelecehan Seksual Terhadap Anak di Indonesia. tribunjakarta.com.

4. Andrei Radu IOVA. (2013). Aspect of the Communication in the Educational System. Case Study, High School Sector. Scientific Papers Series Management, Economic Engineering in Agriculture and Rural Development Vol. 13, Issue 2, p195-198.

5. Anna, Glasier. 2005 Keluarga Berencana dan Kesehatan Reproduksi. Jakarta: EGC.4. 
6. Azwar. Saifuddin 2011. Sikap Manusia Teori dan Pengukurannya. Edisi2. Yogyakarta: Pustaka Pelajar.

7. Badan Pusat Statistik. (2010). Sensus Penduduk Indonesia 2010. Jakarta: Badan Statistik.

8. Badan Pusat Statistik. (2013). Survei Demografi dan Kesehatan Indonesia. (SDKI). Jakarta: Badan Statistik.

9. Bogdan dan Taylor, 1975 dalam J. Moleong, Lexy. (1989) Study Abouth Importance of Effective Listening in Communication of Educational Managemen. Lucrari Stiinntifice, Vol. 54, Issue.2, p344-347

10. Carmen Olguţa Brezuleanui, Stejărel Brezuleanui, Gabriela Ignat. (2011). Study Abouth Importance of Effective Listening in Communication of Educational Managemen. Lucrari Stiinntifice, Vol. 54, Issue.2, p344-347

11. Djuarsa Sendjaja. (2005). Pengantar Komunikasi. Jakarta: Universitas Terbuka.

12. Effendy, O.U. (2004). Dinamika Komunikasi. Bandung: PT. Remaja Rosdakarya.

13. Ilmu Komunikasi Teori dan Praktek. Cetakan kesembilan belas. Bandung: PT Remaja Rosdakarya.

14. Khaidir M. Penyimpangan Seks (Pedofilia). J Kesehat Masy. 2007; 1(2):83-9. 